\title{
Removal of Heavy Metals (Copper and Lead) Using Waste Eggshell with Two Different Species and Three Different Forms
}

\author{
Belgin TUNALI ${ }^{1 *}$, Deniz TÜRKÖZ ALTUĞ ${ }^{(D 2}$, Neslihan KAYA KINAYTÜRK ${ }^{\mathbb{D} 1}$, Cevdet Gökhan TÜZÜN ${ }^{(D)}$ \\ ${ }^{1}$ Burdur Mehmet Akif Ersoy University, Faculty of Arts and Sciences, Department of Nanoscience and Nanotechnology, Burdur \\ ${ }^{2}$ Süleyman Demirel University, Isparta Vocational School of Health Services, East Campus, 32260, Isparta \\ ${ }^{3}$ Isparta University of Applied Sciences, Faculty of Agriculture, Department of Animal Science, Isparta \\ Geliş Tarihi (Received): 15.08.2021, Kabul Tarihi (Accepted): 09.10.2021 \\ $\square$ Sorumlu Yazar (Corresponding author $\left.{ }^{\star}\right)$ : btunali@mehmetakif.edu.tr \\ (C) +902482133029 且 +902482133099
}

\begin{abstract}
Since copper and lead are the most well-known heavy metals, eggshells were used to remove them from the aqueous solution. In this study, it was used two species; Quail (Coturnix coturnix japonica) and Greylag Goose (Anser anser) and three forms (pure, powdered and calcined forms) of eggshells. Using coupled plasma optical emission spectroscopy (ICP-OES), Fourier-transform infrared (FTIR) spectroscopy, scanning electron microscopy (SEM) and energy dispersive spectroscopy (EDS) methods, it was investigated whether copper and lead were adsorbed on eggshells; in different species and different forms. According to ICP-OES results, it was observed that calcined eggshells retained more amount of $\mathrm{Cu}$ and $\mathrm{Pb}$ than uncalcined eggshells. By analyzing the FTIR results, even if the eggshells were in different forms, the characteristic bands of the eggshells were almost seen in samples. After the adsorption process, new bands arose in addition to the characteristic eggshell bands. These new bands are thought to be related to the $\mathrm{Cu}$ and $\mathrm{Pb}$ loading in the eggshell. With SEM images, it was observed that metal loaded accumulated on the outer surface of the eggshell. This result is also in good agreement with the EDS results.
\end{abstract}

Keywords: Copper, eggshell, lead, low-cost adsorbent

\section{İki Farklı Tür ve Üç Farkıı Formda Atık Yumurta Kabuğu Kullanılarak Ağır Me- tallerin (Bakır ve Kurşun) Uzaklaştırılması}

öz

Bakır ve kurşun en iyi bilinen ağır metaller olduğundan, bunların sulu çözeltiden uzaklaştırmak için yumurta kabukları kullanıldı. Bu çalışmada iki tür kullanıldı; bıldırcın (Coturnix coturnix japonica) ve boz kaz (Anser anser) ve yumurta kabuğunun üç formunu (saf, toz ve kalsine formlar) kullandık. Eşleştirilmiş plazma optik emisyon spektroskopisi (ICPOES), Fourier-dönüşümlü kızılötesi (FTIR) spektroskopisi, taramalı elektron mikroskobu (SEM) ve enerji dağılımlı spektroskopi (EDS) yöntemleri kullanılarak, yumurta kabuklarına bakır ve kurşunun adsorbe edilip edilmediği araştırıldı; farklı türlerde ve farklı formlardaki yumurta kabuklarında. ICP-OES sonuçlarına göre, kalsine edilmiş yumurta kabuklarının, kalsine edilmemiş yumurta kabuklarından daha fazla miktarda $\mathrm{Cu}$ ve $\mathrm{Pb}$ tuttuğu gözlemlenmiştir. FTIR sonuçları analiz edildiğinde, yumurta kabukları farklı formlarda olsa bile, örneklerde yumurta kabuklarının karakteristik bantları hemen hemen aynı bölgelerde görülmüştür. Adsorpsiyon işleminden sonra karakteristik yumurta kabuğu bantlarına ek olarak yeni bantlar ortaya çıkmıştır. Bu yeni bantların yumurta kabuğundaki $\mathrm{Cu}$ ve $\mathrm{Pb}$ yüklü olmasıyla ilgili olduğu düşünülmektedir. SEM görüntüleri ile yumurta kabuğunun dış yüzeyinde metalin biriktiği gözlenmiştir. Bu sonuç, EDS sonuçlarıyla da iyi bir uyum içindedir.

Anahtar Kelimeler: Bakır, yumurta kabuğu, kurşun, ucuz adsorbent

Belgin TUNALI, https://orcid.org/0000-0003-0768-679X Deniz TÜRKÖZ ALTUĞ, https://orcid.org/0000-0002-1861-6263

Neslihan KAYA KINAYTÜRK, https://orcid.org/0000-0002-2170-1223

Cevdet Gökhan TÜZÜN, https://orcid.org/0000-0002-4778-6202 


\section{INTRODUCTION}

Environmental pollution significantly affects the health of living things. Heavy metals, which have the feature of accumulating in nature because they are not biodegradable, are dangerous for living things when they exceed certain limits (Veli and Alyuz, 2007). Adsorption is an easy and inexpensive method for removing heavy metals from aqueous solutions. The adsorption process takes a very short time and is the most preferred method to remove heavy metals by adsorption due to its ease of use and simplicity (Alaba et al., 2018; Musonge and Harripersadth, 2021). Biosorbents are used effectively to remove heavy metals from the environment (Yang et al., 2021). In addition, biosorbents do not cause additional harm to the environment and do not release substances that may be harmful to the environment. Egg is one of the most used, easily accessible, cheap and basic food sources in daily life. Since their shells are sometimes rich in calcium content, they are used in the pharmaceutical and food industry as a source of calcium (Waheed et al., 2019), as a bio-ceramic (Tangboriboon et al., 2019), composite (Feng et al., 2014), fertilizer (King'Ori, 2011) and biosorbent (Podstawczyk et al., 2014), while they are often thrown away, especially in household use. However, the physical and chemical structures of the eggshells are very suitable as biosorbents. Specially, porous structure and electronegativity due to $\mathrm{CaCO}_{3}$ in its chemical content are desirable and preferred adsorbate property for adsorption (Wang et al., 2018; Kaya Kınaytürk et al., 2021). Adsorption process for removing heavy metals from the environment is one of the most preferred processes due to its strong affinity and high loading capacity. Moreover, they are costfree as they are waste materials (Musonge and Harripersadth, 2021). Since they have gotten porous and layer-by-layer structure and they can adsorb heavy metals, or they can trap many pollutants, dyes and organics. In addition, the calcined state can absorb much more amount of heavy metals than its natural state (Park et al., 2007). $\mathrm{Pb}^{2+}$ is considered a potential carcinogen and associated with the cause of many diseases, especially cardiovascular, kidney, blood, nerve and bone diseases. $\mathrm{Cu}^{2+}$ is an essential element, but its high concentrations in food and fodder crops are great concern due to increased toxicity to humans and animals (Hashmi et al., 2013). It is important to remove heavy metals such as copper and lead from the environment before reaching irrigation water in agriculture. At the same time, removing heavy metals from drinking water can prevent living things from damaging organs in their bodies. Therefore, many researchers have proposed various methods to purify heavy metals from aqueous solutions (Gebru and Das, 2017; Yu et al.,
2021). Some of these are chemical precipitation, coagulation, ion exchange, solvent extraction, filtration, evaporation and membrane methods (Park et al., 2007). The disadvantage is that most of these methods require a few pre-processes and additional operations. In this study, eggshell residue was used as a biosorbent material. The aim is to remove $\mathrm{Pb}^{2+}$ and $\mathrm{Cu}^{2+}$ from the aqueous solution. At the same time, we recycle the waste eggshell. We used two types of eggshells in three different forms. Types (species) of eggshells were Quail (Coturnix coturnix japonica (CCJ) and Greylag Goose (Anser anser $(A A)$ ). Three different forms were 1-pure eggshell, 2-powdered eggshell, 3calcined eggshell. We used $\mathrm{CuCl}_{2}$ and $\mathrm{Pb}\left(\mathrm{NO}_{3}\right)_{2}$ as metal salts in the experiments. After preparation in aqueous solutions of copper and lead heavy metal salts, we examined the adsorption phenomenon for each sample in the respective eggshell type and form. Abbreviations are made as follows:

CCJ: pure quail eggshell

AA: pure grey goose eggshell

C-CCJ: calcined quail eggshell

C-AA: calcined grey goose eggshell

$\mathrm{Cu} @ \mathrm{CCJ}: \mathrm{CCJ}$ treated with $\mathrm{CuCl}_{2}$

$\mathrm{Pb@CCJ:} \mathrm{CCJ} \mathrm{treated} \mathrm{with} \mathrm{Pb}\left(\mathrm{NO}_{3}\right)$

$\mathrm{Cu} @ \mathrm{C}-\mathrm{CCJ}: \mathrm{C}-\mathrm{CCJ}$ treated with $\mathrm{CuCl}_{2}$

$\mathrm{Pb} @ \mathrm{C}-\mathrm{CCJ}$ : C-CCJ treated with $\mathrm{Pb}\left(\mathrm{NO}_{3}\right)_{2}$

$\mathrm{Cu@AA:} \mathrm{AA} \mathrm{with} \mathrm{treated} \mathrm{CuCl}_{2}$

$\mathrm{Pb} @ A A: A A$ with treated $\mathrm{Pb}\left(\mathrm{NO}_{3}\right)_{2}$

$\mathrm{Cu} @ \mathrm{C}-\mathrm{AA}: \mathrm{C}-\mathrm{AA}$ with treated $\mathrm{CuCl}_{2}$

$\mathrm{Pb@C-AA:} \mathrm{C-AA} \mathrm{with} \mathrm{treated} \mathrm{Pb}\left(\mathrm{NO}_{3}\right)_{2}$

\section{MATERIALS AND METHODS}

\section{Materials and Chemicals}

Eggshell samples $C C J$ and $A A$ were obtained from Isparta University of Applied Sciences, Education Research and Application Farm. Eggshell samples were taken from incubation wastes of this farm. The compounds of $\mathrm{Pb}\left(\mathrm{NO}_{3}\right)_{2}$ and $\mathrm{CuCl}_{2}$ in solid form were purchased from Sigma-Aldrich chemical company (USA) and they were used without further purification.

\section{Experimental}

The cleaning procedure in our previous article was applied to $C C J$ and $A A$ eggshells (Kaya Kınaytürk et al., 2021). We used samples in three different forms: shell form, powdered form, calcined form. Shell form needed no further process on it. For powdered form we ground samples in an agate mortar, for calcined form, 
this part was calcined at $900 \mathrm{C}^{\circ}$ for 2 hours. The schematic representation and photographs were shown in Figure 1.

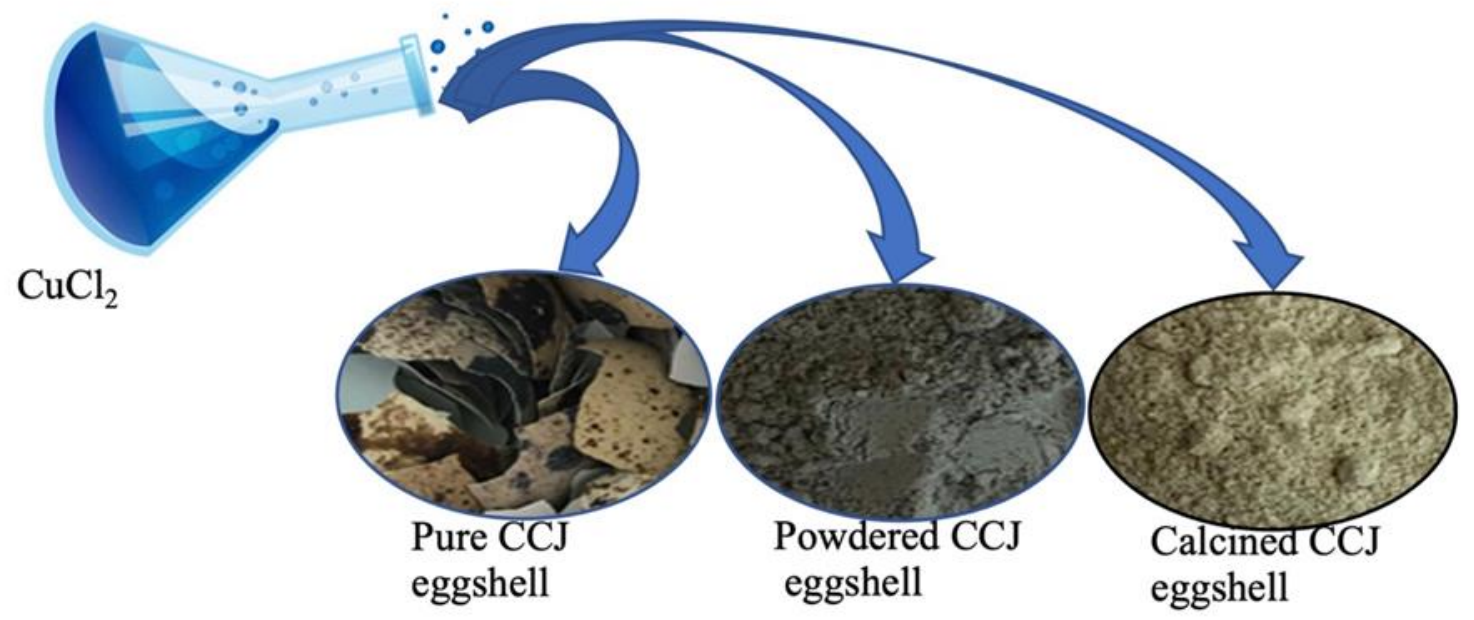

Figure 1. Pure, powdered and calcined CCJ of eggshells treated with $\mathrm{CuCl}_{2}$

$0.05 \mathrm{M}, 100 \mathrm{~mL} \mathrm{~Pb}\left(\mathrm{NO}_{3}\right)_{2}$ and $\mathrm{CuCl}_{2}$ solutions were prepared with ultra-distilled $(18,2 \Omega)$ water. $1 \mathrm{~g}$ of each eggshells samples were mixed with $0.05 \mathrm{M}, 100 \mathrm{~mL}$ $\mathrm{Pb}\left(\mathrm{NO}_{3}\right)_{2}$ and $\mathrm{CuCl}_{2}$ solutions in an ultrasonic bath. After that, they were shaken from time to time and adsorption was applied for 48 hours. Filter and dried eggshells samples were analyzed by FTIR spectroscopy, ICP-OES and SEM. In addition to that, to investigate the differences we used all analytical techniques for pure eggshell samples.

Before ICP-OES analyses, samples were prepared as follows: $0,25 \mathrm{~g}$ sample $+4 \mathrm{~mL} 65 \% \mathrm{HNO}_{3}+2 \mathrm{~mL} 40$ $\% \mathrm{HF}+2 \mathrm{~mL} 98 \% \mathrm{H}_{2} \mathrm{SO}_{4}$ and Milestone Start D model microwave digestion system used, with Perkin Elmer ICP-OES The Optima 8000 in MAKÜ (Burdur Mehmet Akif Ersoy University), BILTEKMER (Scientific and Technology Application and Research Center) Burdur, Turkey. FTIR analyses were performed with Perkin
Elmer Spectrum Fronter device using $\mathrm{KBr}$ pellet technique in the range of $4000-400 \mathrm{~cm}^{-1}$ in BILTEKMER. SEM and EDS analyses have been used to record the morphological data and the elemental composition of the samples with FEI Quanta FEG 250 in SDU (Süleyman Demirel University), YETEM (Innovative Technologies Application and Research Center), Isparta, Turkey.

\section{RESULTS AND DISCUSSION ICP-OES Results}

The ICP-OES were used to determine the amount of heavy metal on eggshells after adding metallic aqueous solution on the uncalcined and calcined form of eggshells. They are also listed in Table $1 \mathrm{as} \mathrm{mg} / \mathrm{kg}$. In each type of eggshell, copper is less abundant on specimens. When looking at the same eggshell species, metals are more abundant in calcined eggshell form than uncalcined.

Table 1. Amounts of copper and lead on powdered and calcined form of eggshells

\begin{tabular}{|l|l|l|l|}
\hline & Cu (mg/kg) & & Pb (mg/kg) \\
\hline Cu@CCJ & 9920,729 & Pb@CCJ & 329827,916 \\
\hline Cu@C-CCJ & 13496,012 & Pb@C-CCJ & 365295,926 \\
\hline Cu@AA & 199743,213 & Pb@AA & 318076,028 \\
\hline Cu@C-AA & 203998,447 & Pb@C-AA & 353325,416 \\
\hline
\end{tabular}

When Table 1 is examined, it was seen that copper and lead heavy metals were adhering to the eggshell in each form. More heavy metals were retained in calcined eggshells than in uncalcined eggshells. It is thought that the 
reason of this increase was that when the eggshells were calcined, more heavy metal has adhered because the surface area increases (Park et al., 2007).

\section{FTIR Spectroscopic Results}

Since metal is adsorbed on the different forms of the eggshell, FTIR analysis can give an idea or clue about the location of the metal ion. Figure 2 and Table 2 show that the IR spectra and assignments list of CCJ, C-CCJ, Cu@CCJ,Pb@CCJ, Cu@C-CCJ, Pb@C-CCJ, respectively.

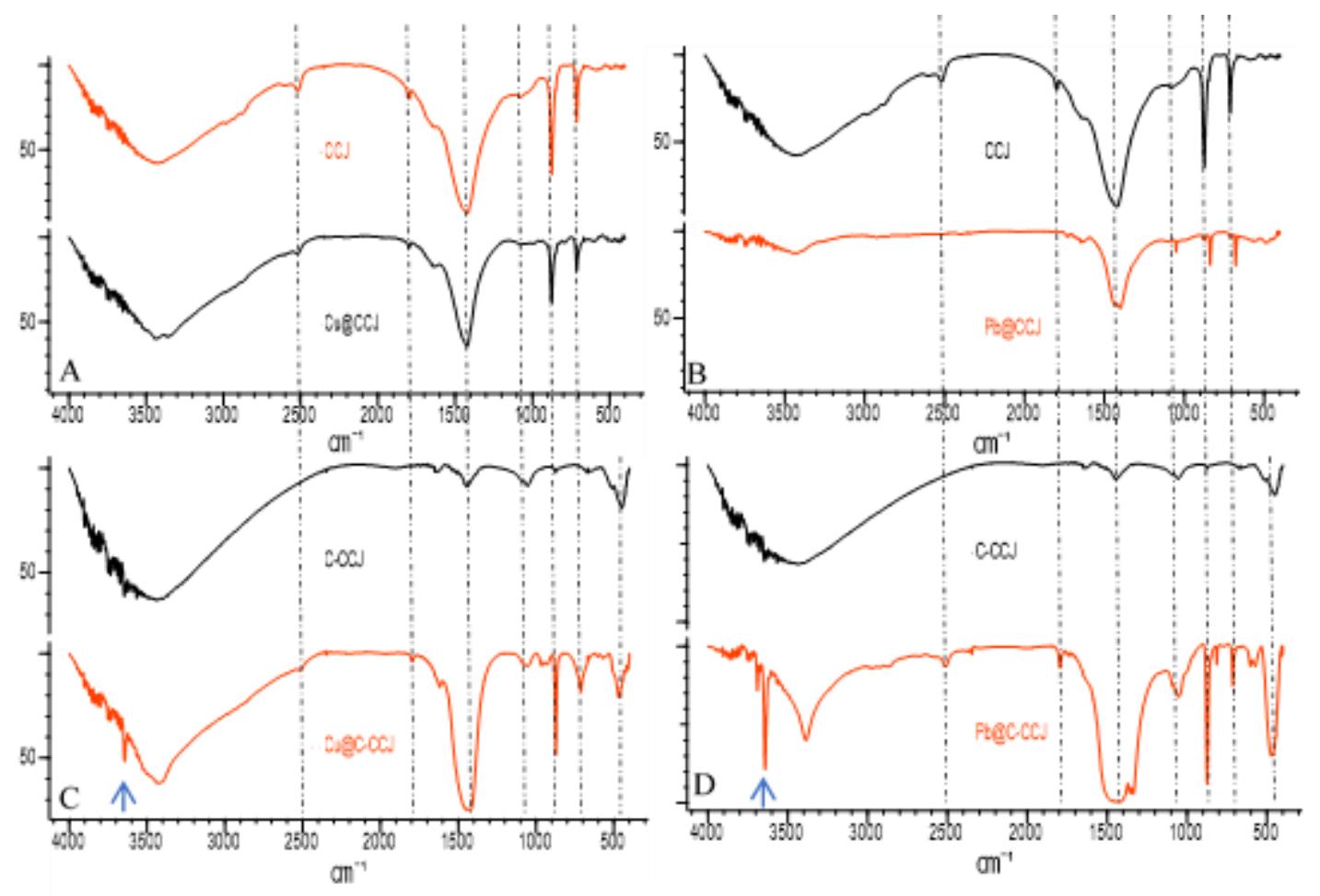

Figure 2. (A) CCJ and Cu@CCJ (B) CCJ and Pb@CCJ (C) C-CCJ and Cu@C-CCJ (D) C-CCJ and Pb@C-CCJ 
Table 2. IR assignments of different forms of CCJ eggshell

\begin{tabular}{|c|c|c|c|c|c|c|c|}
\hline Assignments & References & CCJ & Cu@CCJ & Pb@CCJ & C-CCJ & Cu@C-CCJ & $\mathrm{Pb@C-CCJ}$ \\
\hline $\mathrm{OH}$ stretch & $\begin{array}{l}3688 \text { (Park et } \\
\text { al., 1988) }\end{array}$ & & & & & & $3690 \mathrm{~m}$ \\
\hline $\mathrm{OH}$ stretch & $\begin{array}{l}3643 \\
\text { (Naemchan et } \\
\text { al., 2008) }\end{array}$ & & & & & & $3641 \mathrm{~s}$ \\
\hline $\begin{array}{l}\mathrm{CO}_{3}^{-2} \text { stretch- } \\
\text { ing }\end{array}$ & $\begin{array}{lr}2516 \quad \text { Kaya } \\
\text { Kınaytürk et } \\
\text { al., 2021) }\end{array}$ & $2516 \mathrm{w}$ & $2516 w$ & $2516 w$ & - & $2515 w$ & $2511 w$ \\
\hline $\begin{array}{l}\mathrm{CO}_{3}^{-2} \text { stretch- } \\
\text { ing }\end{array}$ & $\begin{array}{lr}1799 \quad \text { Kaya } \\
\text { Kınaytürk et } \\
\text { al., 2021) }\end{array}$ & $1799 w$ & $1799 w$ & 1799vw & - & $1797 w$ & $1794 w$ \\
\hline $\mathrm{NO}_{2}$ stretching & $\begin{array}{l}1727 \text { (Bhatia } \\
\text { et al., 1983) }\end{array}$ & & & $1728 \mathrm{~m}$ & & & $1735 v w$ \\
\hline $\begin{array}{l}\text { Carbonyl } \\
\text { group stretc- } \\
\text { hing }\end{array}$ & $\begin{array}{l}1645 \text { (Tizo et } \\
\text { al., 2018) }\end{array}$ & 1631sh & 1631sh & 1638sh & 1632sh & 1617sh & 1632sh \\
\hline $\begin{array}{l}\mathrm{CO}_{3}^{-2} \text { stretch- } \\
\text { ing }\end{array}$ & $\begin{array}{lr}1424 \quad \text { Kaya } \\
\text { Kınaytürk et } \\
\text { al., 2021) }\end{array}$ & $1424 \mathrm{~s}$ & & $1435 s$ & $1444 \mathrm{~m}$ & & $1435 s$ \\
\hline C-O stretch & $\begin{array}{l}1408 \text { (Basaleh } \\
\text { et al., 2019) }\end{array}$ & & & $1403 s$ & & & 1354s \\
\hline $\begin{array}{l}\mathrm{CO}_{3}^{-2} \text { stretch- } \\
\text { ing }\end{array}$ & $\begin{array}{lr}1082 \text { (Kaya } \\
\text { Kınaytürk et } \\
\text { al., 2021) } \\
\end{array}$ & $1082 \mathrm{sh}$ & 1082sh & 1105sh & $\begin{array}{l}\text { 1093sh- } \\
1056 \mathrm{~m}\end{array}$ & $\begin{array}{l}\text { 1093sh- } \\
1056 \mathrm{~m}\end{array}$ & $\begin{array}{l}\text { 1093sh- } \\
1051 \mathrm{~m}\end{array}$ \\
\hline $\mathrm{N}-\mathrm{O}$ stretching & $\begin{array}{l}1072 \text { (Zhang } \\
\text { et al., 2021) }\end{array}$ & & & $1052 m$ & & & \\
\hline $\begin{array}{l}\mathrm{CO}_{3}^{-2} \text { in plane } \\
\text { deformation }\end{array}$ & $\begin{array}{l}875 \text { (Kaya } \\
\text { Kınaytürk et } \\
\text { al., 2021) }\end{array}$ & $875 \mathrm{~m}$ & & $872 s$ & $876 w$ & $872 s$ & $873 s$ \\
\hline $\begin{array}{l}\mathrm{C}-\mathrm{H} \text { out of } \\
\text { plane }\end{array}$ & $\begin{array}{l}802 \text { (de Luna } \\
\text { et al., 2015) }\end{array}$ & & $822 w$ & $839 m$ & & - & $814 m$ \\
\hline $\begin{array}{l}\mathrm{CCl}_{3} \text { stretch- } \\
\text { ing }\end{array}$ & $\begin{array}{l}784 \\
\text { (Wallington et } \\
\text { al., 2000) }\end{array}$ & & $788 w$ & & & - & \\
\hline $\begin{array}{ll}\mathrm{CO}_{3}^{-2} & \text { out of } \\
\text { plane } & \text { defor- } \\
\text { mation } & \\
\end{array}$ & $\begin{array}{lr}713 \quad \text { Kaya } \\
\text { Kınaytürk et } \\
\text { al., 2021) }\end{array}$ & $713 \mathrm{~m}$ & $713 m$ & $713 w$ & - & $711 \mathrm{~m}$ & $711 \mathrm{~s}$ \\
\hline $\begin{array}{ll}\mathrm{NO}_{3}^{-} & \text {stretch- } \\
\text { ing } & \end{array}$ & $\begin{array}{l}721 \text { (Reddy et } \\
\text { al., 2015) }\end{array}$ & & & $679 s$ & & & $677 s$ \\
\hline $\mathrm{Ca}-\mathrm{O}$ & $\begin{array}{l}447 \text { (Pandit } \\
\text { and Fulekar, } \\
2017)\end{array}$ & & & & $447 m$ & $468 m$ & $474 s$ \\
\hline
\end{tabular}

s; strong, sh; shoulder, w; weak, m; medium means the intensity of the peaks

When Figure 2 and Figure 3 were examined, it wasn't clearly seen around $3640 \mathrm{~cm}^{-1}$ which belonged to $\mathrm{OH}$ stretching band in the uncalcined samples. It was observed after treated with heavy metals on calcined

forms. This band was attributed $\mathrm{OH}^{-}$band (Naemchan et al., 2008; Putra et al., 2017). While after calcination process, calcined eggshell shows the existence of $\mathrm{OH}$ in $\mathrm{Ca}(\mathrm{OH})_{2}$ in the peak of around $3643 \mathrm{~cm}^{-1}$ (Naemchan et al., 2008). It was formed during adsorption of water by $\mathrm{CaO}$ (Renu et al., 2017). The bands around 3400-3600 $\mathrm{cm}^{-1}$ were caused by the vibration of water molecules in the uncalcined and calcined samples (Naemchan et al., 2008). 2516, 1799, 1424, 1082, 875 and $713 \mathrm{~cm}^{-1}$ are characteristic peaks of eggshells (Kaya Kınaytürk et al., 2021), (Anjaneyulu and Sasikumar, 2014; Awogbemi et al., 2020). One of the studies, the band at $2506 \mathrm{~cm}^{-1}$ was assigned to carbonate vibration (Tatzber et al., 2007). In this study, this band was seen at $2516 \mathrm{~cm}^{-1}$ that was observed at the same position, in our previous study (Kaya Kınaytürk et al., 2021). The band at $1799 \mathrm{~cm}^{-1}$ observed in pure eggshells disappeared after calcination but it was 
clearly visible after treatment with aqueous metal solution. The weak band around $1799 \mathrm{~cm}^{-1}$ and a shoulder around $1084 \mathrm{~cm}^{-1}$ have corresponded to $\mathrm{C}=\mathrm{O}$ bonds related to carbonate and the symmetric stretching of $\mathrm{CO}_{3}$, respectively (Kazemi et al., 2017; Queiros et al., 2017). The band at around $1640 \mathrm{~cm}^{-1}$ can be attributed to the carbonyl group vibration (Tizo et al., 2018). The peak, which was the C-O stretching belongs to the symmetrical vibration of carbonate around $1424 \mathrm{~cm}^{-1}$, was seen as the deepest peak in all eggshell forms (Eletta et al., 2016; Yusuff, 2017; Kaya Kınaytürk et al., 2021). The small bands around 874 and $712 \mathrm{~cm}^{-1}$ were attributed to the out-of-plane and in-plane deformation vibration bands of $\mathrm{CaCO}_{3}$, respectively (Tsai et al., 2006; Kit, et al., 2020; Kaya Kınaytürk et al., 2021). In addition, generally sharp vibration band at $872 \mathrm{~cm}^{-1}$ was seen more deeply, especially in calcined form eggshell and treated with aqueous metal solution eggshell forms. This peak is evidence of the $\mathrm{CaCO}_{3}$ in the eggshell structure.

When Figure 2(A) is investigated, the weak vibrational band at $788 \mathrm{~cm}^{-1}$ in Cu@CCJ was thought to arise as a result of the interaction of $\mathrm{Cl}$ between the surface of eggshell (Bae et al., 2006). The $\mathrm{CH}$ band at $802 \mathrm{~cm}^{-1}$ in the literature was seen as a weak band at $822 \mathrm{~cm}^{-1}$ in our study after treatment of copper aqueous solution (de Luna et al., 2015).

When Figure 2(B) is examined, a new weak band in $\mathrm{Pb} @ \mathrm{CCJ}$ was observed at $1728 \mathrm{~cm}^{-1}(\mathrm{~N}-\mathrm{O})$ which was thought to be caused by $\mathrm{NO}_{2}$ (Bhatia et al., 1983). The shift of C-O peak from 1408 to $1403 \mathrm{~cm}^{-1}$ in the $\mathrm{Pb@CCJ} \mathrm{spectrum} \mathrm{might} \mathrm{be} \mathrm{ascribed} \mathrm{to} \mathrm{the} \mathrm{interaction}$ between $\mathrm{Pb}(\mathrm{II})$ ions and carbonate group on CCJ surface (Basaleh et al., 2019). The $\mathrm{CH}$ band detected at
$802 \mathrm{~cm}^{-1}$ in the literature, which was not observed in pure eggshell, was seen at $839 \mathrm{~cm}^{-1}$ after treatment with $\mathrm{Pb}$ aqueous solution (de Luna et al., 2015). A new medium band in Pb@CCJ was arise at $1052 \mathrm{~cm}^{-1}$ which was thought to be caused by NO stretching (Zhang et al., 2021). The $\mathrm{CH}$ and $\mathrm{NO}_{3}{ }^{-}$vibration bands were seen at $839 \mathrm{~cm}^{-1}$ (de Luna et al., 2015). and $679 \mathrm{~cm}^{-1}$ (Reddy et al., 2015), respectively.

When Figure 2(C) is investigated, characteristic bands of C-CCJ were seen at 1632, 1444, 1093, 1056, 876 and $447 \mathrm{~cm}^{-1}$ (Pandit and Fulekar, 2017). The vibration band at $447 \mathrm{~cm}^{-1}$ was thought to belong to $\mathrm{CaO}$ (Pandit and Fulekar, 2017). This band was shifted to $468 \mathrm{~cm}^{-1}$ in Cu@C-CCJ.

When Figure 2(D) is examined, the C-O peak at 1408 $\mathrm{cm}^{-1}$ in literature shifted to $1354 \mathrm{~cm}^{-1}$ in Pb@C-CCJ. The C-O vibration band at $1056 \mathrm{~cm}^{-1}$ in C-CCJ was observed to shift to $1051 \mathrm{~cm}^{-1}$ in $\mathrm{Pb} @ \mathrm{C}-\mathrm{CCJ}$. The reason of this shift may be caused by the interaction of eggshells and Lead ions. The $\mathrm{CaO}$ vibration band at $447 \mathrm{~cm}^{-1}$ in C-CCJ shifted to $474 \mathrm{~cm}^{-1}$. The reason of this shift was thought to be due to the interaction of the aqueous solution of the lead and the eggshells. In addition, new bands were seen at 1735 and $677 \mathrm{~cm}^{-1}$ in Pb@C-CCJ. These bands were attributed to result from $\mathrm{NO}_{2}$ (Bhatia et al., 1983) and $\mathrm{NO}_{3}{ }^{-}$(Reddy et al., 2015), stretching, respectively. The $\mathrm{CH}$ band observed at $802 \mathrm{~cm}^{-1}$ in the literature was observed at $814 \mathrm{~cm}^{-1}$ in Pb@C-CCJ (de Luna et al., 2015).

Figure 3 and Table 3 show the IR spectra and assignments of AA, C-AA, Cu@AA, Pb@AA, Cu@C-AA, $\mathrm{Pb} @ \mathrm{C}-\mathrm{AA}$, respectively. 

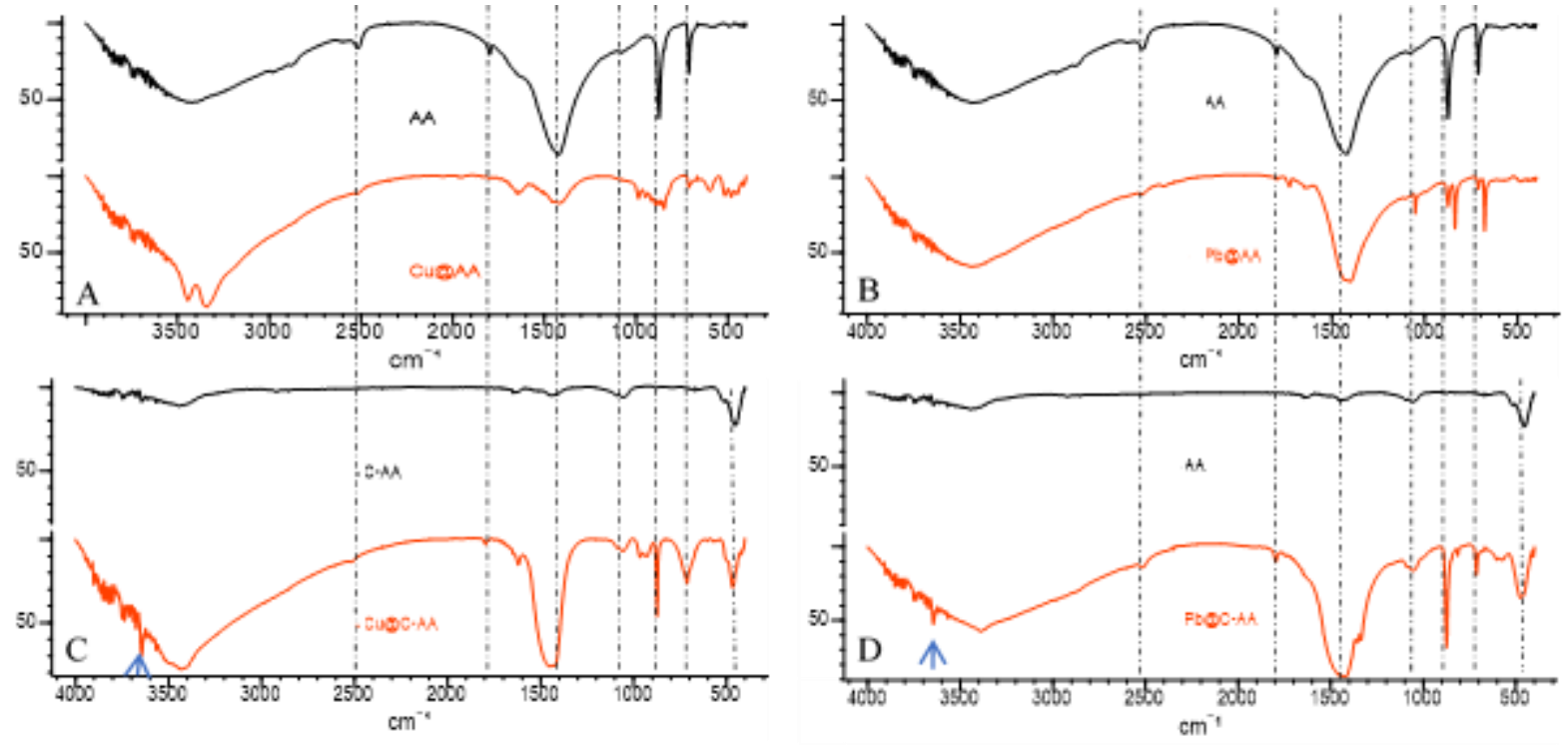

Figure 3. (A) AA and Cu@AA (B) $A A$ and Pb@AA (C) C-AA and Cu@C-AA (D) C-AA and Pb@C-AA

Table 3. IR assignments of different forms of $A A$ eggshell

\begin{tabular}{|c|c|c|c|c|c|c|c|}
\hline Assignments & References & AA & Cu@AA & Pb@AA & C-AA & $\begin{array}{l}\text { Cu@C- } \\
\text { AA }\end{array}$ & $\begin{array}{l}\mathrm{Pb} @ \mathrm{C}- \\
\mathrm{AA}\end{array}$ \\
\hline $\mathrm{OH}$ & $\begin{array}{l}3643 \\
\text { (Naemchan et } \\
\text { al., 2008) }\end{array}$ & & & & & & $3646 \mathrm{~m}$ \\
\hline $\mathrm{CO}_{3}^{-2}$ stretching & $\begin{array}{ll}2516 & \text { (Kaya } \\
\text { Kınaytürk et al., } \\
2021)\end{array}$ & $2516 \mathrm{~m}$ & $2516 w$ & $2516 w$ & - & $2516 w$ & $2516 w$ \\
\hline $\mathrm{CO}_{3}^{-2}$ stretching & $\begin{array}{l}1799 \quad \text { Kaya } \\
\text { Kınaytürk, et al., } \\
2021)\end{array}$ & $1800 \mathrm{~m}$ & $1800 \mathrm{vw}$ & $1800 w$ & - & 1796w & $1796 w$ \\
\hline $\mathrm{NO}_{2}$ stching & $\begin{array}{l}1727 \text { (Bhatia et } \\
\text { al., 1983) }\end{array}$ & & & $1729 \mathrm{~m}$ & & & - \\
\hline Carbonyl group stretching & $\begin{array}{l}1645 \text { (Tizo et al., } \\
2018 \text { ) }\end{array}$ & 1630sh & $1645 \mathrm{~m}$ & $1645 \mathrm{~m}$ & $1635 \mathrm{~m}$ & $1621 w$ & 1629sh \\
\hline $\mathrm{CO}_{3}^{-2}$ stretching & $\begin{array}{l}1424 \quad \text { Kaya } \\
\text { Kınaytürk et al., } \\
2021)\end{array}$ & $1424 s$ & & $1424 s$ & $1441 \mathrm{~m}$ & & $1435 s$ \\
\hline C-O stretch & $\begin{array}{l}1408 \text { (Basalehet } \\
\text { al., 2019) }\end{array}$ & & & 1397s & & & 1356sh \\
\hline $\mathrm{CO}_{3}^{-2}$ stretching & $\begin{array}{ll}1082 & \text { (Kaya } \\
\text { Kınaytürk et al., } \\
2021)\end{array}$ & 1082sh & - & $1104 \mathrm{sh}$ & $\begin{array}{l}\text { 1091sh- } \\
1055 \mathrm{~m}\end{array}$ & $\begin{array}{l}\text { 1090sh- } \\
1056 \mathrm{~m}\end{array}$ & $\begin{array}{l}\text { 1092sh- } \\
1052 \mathrm{~m}\end{array}$ \\
\hline $\mathrm{N}-\mathrm{O}$ stretching & $\begin{array}{l}1072 \text { (Zhang et } \\
\text { al., 2021) }\end{array}$ & & & $1051 \mathrm{~m}$ & & & \\
\hline $\mathrm{CO}_{3}^{-2}$ in plane deformation & $\begin{array}{ll}875 & \text { (Kaya } \\
\text { Kınaytürk et al., } \\
\text { 2021) }\end{array}$ & $874 s$ & $872 s$ & $874 m$ & $877 w$ & $873 s$ & \\
\hline $\mathrm{C}-\mathrm{H}$ out of plane & $\begin{array}{l}802 \text { (de Luna et } \\
\text { al., 2015) }\end{array}$ & & $849 w$ & $837 s$ & & & $814 m$ \\
\hline $\begin{array}{l}\mathrm{CO}_{3}^{-2} \text { out of plane defor- } \\
\text { mation }\end{array}$ & $\begin{array}{ll}713 & \text { (Kaya } \\
\text { Kınaytürk et al., } \\
\text { 2021) }\end{array}$ & $712 \mathrm{~s}$ & $712 w$ & $712 w$ & - & $713 w$ & $713 m$ \\
\hline $\mathrm{NO}_{3}-$ stretch & $\begin{array}{l}721 \text { (Reddy et } \\
\text { al., 2015) }\end{array}$ & & & $677 \mathrm{~m}$ & & & - \\
\hline $\mathrm{Ca}-\mathrm{O}$ & $\begin{array}{l}447 \text { (Pandit and } \\
\text { Fulekar, 2017) }\end{array}$ & & & & $455 s$ & $467 \mathrm{~m}$ & $474 s$ \\
\hline
\end{tabular}


When Figure 3(A) was investigated, the peak at $849 \mathrm{~cm}-$ ${ }^{1}$ was attributed $\mathrm{CH}$ out of plane in Cu@AA, (de Luna et al., 2015). When Figure $3(B)$ was examined, the characteristic band of the C-O vibration at $1082 \mathrm{~cm}^{-1}$ in Pb@AA was seen to shift to $1104 \mathrm{~cm}^{-1}$. The reason of this shift was thought due to the loaded of lead on the surface of eggshell. All other characteristic bands of eggshells were seen. In addition, bands at 1729, 1397,1051,837 and $677 \mathrm{~cm}^{-1}$ were thought that it might belong to the vibrations of $\mathrm{NO}_{2}$ (Bhatia et al., 1983), $\mathrm{CO}$ (Basaleh et al., 2019), N-O (Zhang et al., 2021), CH (de Luna et al., 2015), $\mathrm{NO}_{3}$ - (Reddy et al.,2015), respectively. When Figure $3(C)$ is investigated, characteristic bands for calcined goose eggshell; 1635, 1441, 1091, 1055 and 877 $\mathrm{cm}^{-1}$ were also observed. The vibration band at $455 \mathrm{~cm}$ 1 in the C-AA and thought to belong to $\mathrm{Ca}-\mathrm{O}$ which was shifted to $467 \mathrm{~cm}^{-1}$ in Cu@C-AA. When we investigated the peaks in Figure 3(D), the shoulder band at $1356 \mathrm{~cm}^{-}$
${ }^{1}$ was attributed to C-O stretching in Pb@C-AA. In addition, newly band arose at $814 \mathrm{~cm}^{-1}$ in Pb@C-CCJ. This band was thought to result from $\mathrm{C}-\mathrm{H}$ out of plane vibration (de Luna et al., 2015). The vibrational band of $\mathrm{Ca}-\mathrm{O}$ at $455 \mathrm{~cm}^{-1}$ in C-AA was seen to be shifted to $474 \mathrm{~cm}^{-1}$ in Pb@C-AA (Pandit and Fulekar, 2017).

\section{SEM-EDS Results}

Figure 4 shows SEM images for eggshells in different forms. The SEM images were taken as a cross section. Thus, it was investigated whether the contents of the unpowdered eggshells and heavy metals were included. When Figure 4 is examined, bright parts show areas covered with metal in Figure 4A-C-E-F. In Figures 4A and $D$, the eggshells were seen as 4 layers.

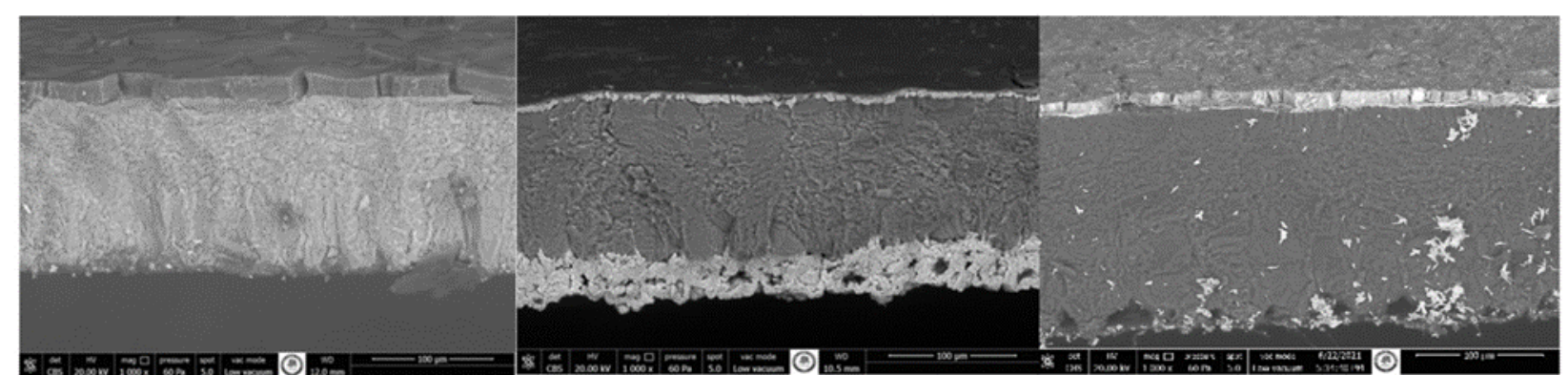

(A)CCJ

(B) $\mathrm{Cu} @ \mathrm{CCJ}$

(C) Pb@CCJ

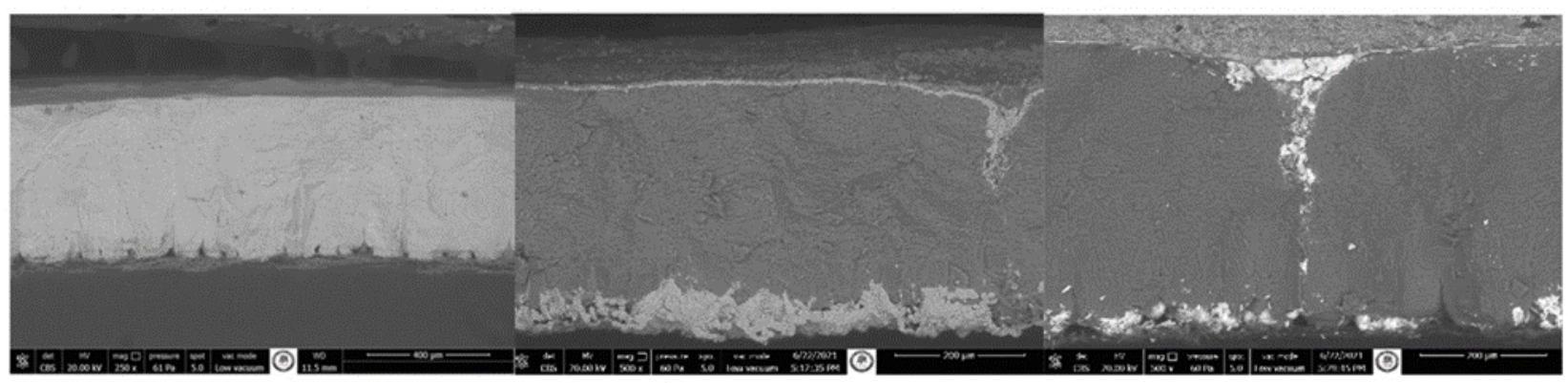
(D) $\mathrm{AA}$
(E) $\mathrm{Cu} @ \mathrm{AA}$
(F) $\mathrm{Pb} @ \mathrm{AA}$

Figure 4. SEM photographs of CCJ, Cu@CCJ, Pb@CCJ, AA, Cu@AA and Pb@AA 


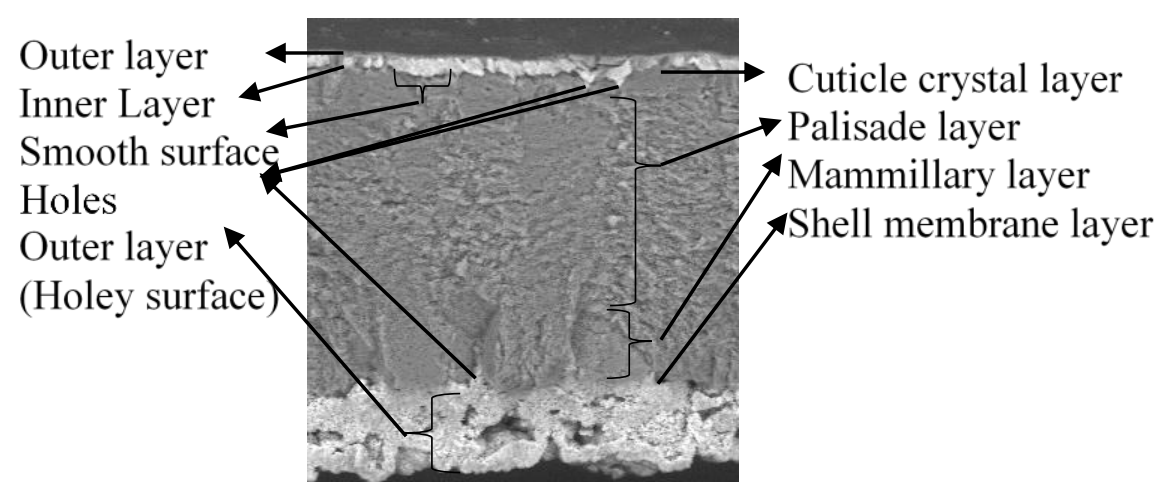

Figure 5. Eggshell layers

These layers are cuticle crystal layer, palisade layer, mammillary layer and shell membrane layer from top to bottom (Figure 5) (Hincke et al., 2008; Pérez-Huerta and Dauphin, 2016). Heavy metals were seen to accumulate on the outer surface of the eggshells. On the holey surfaces, it was observed that heavy metals penetrate inside, but unsurprisingly, heavy metals could not penetrate into the smooth surface of the eggshells. While the $\mathrm{Cu}$ residues in Figure 4B and $\mathrm{E}$ were 2 layers on the cuticle crystal layer of the eggshells, the $\mathrm{Pb}$ residues in
Figure $4 \mathrm{C}$ and $\mathrm{F}$ were seen as a single layer accumulation. In Figure 4C, the bright parts in the palisade and mammillary layers are copper residues smeared from the outer part of the eggshell when taking SEM images. These results were also proven by the EDS results in Figure 6. The EDS results from inner and outer layers upon the cuticle crystal layers of Cu@CCJ and Cu@AA were shown in Figure 6. 


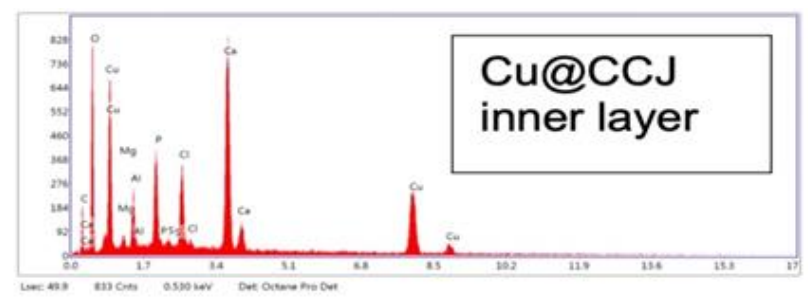

EZAF Sman Quant Results
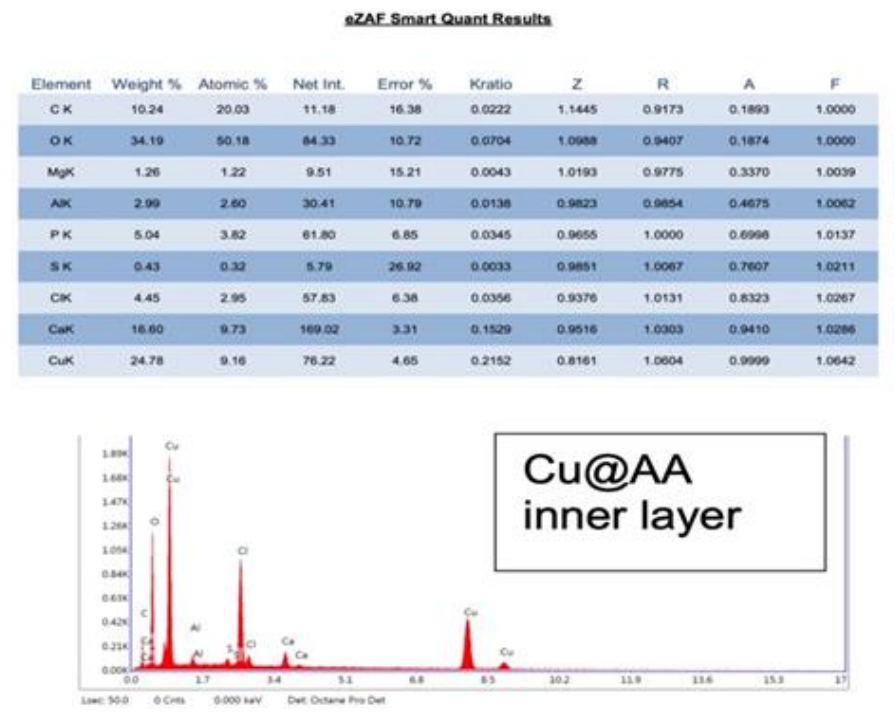

eZAF Smart Quant Results

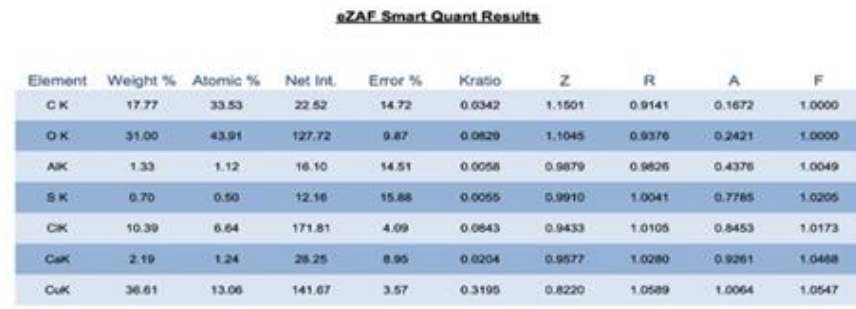

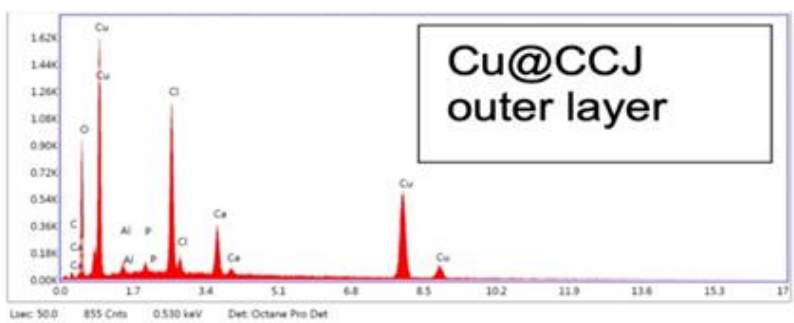
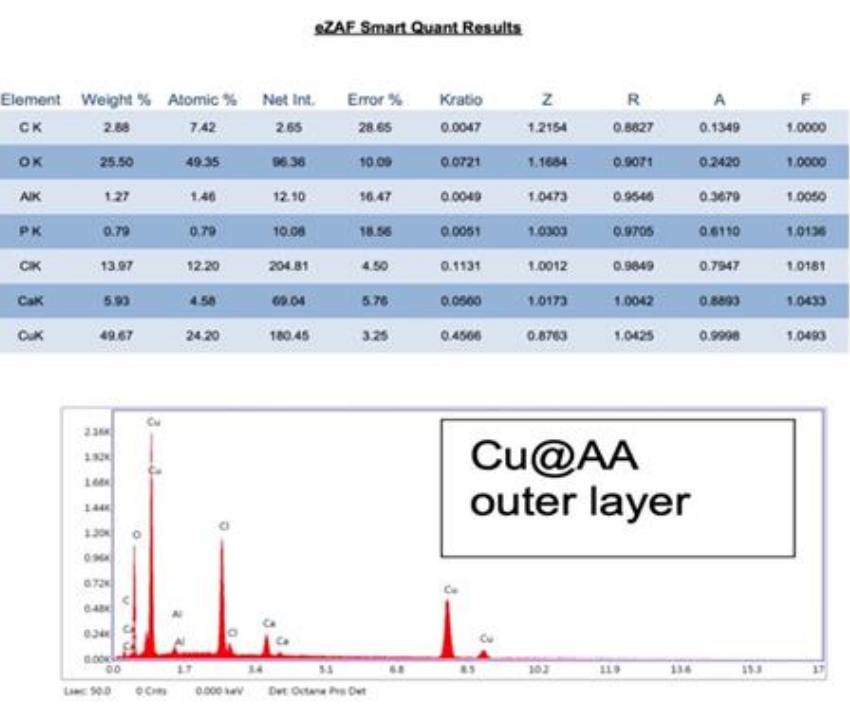

eZAF Smant Quant Results

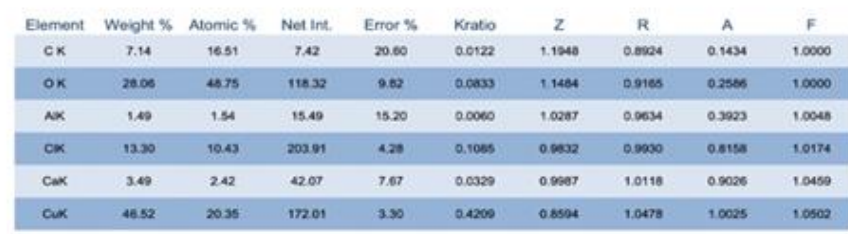

Figure 6. EDS results for Cu@CCJ and Cu@AA at inner and outer layers upon the cuticle crystal layer

According to EDS results, copper and lead residues were accumulated on outer layer of eggshells. Regardless of the type of eggshell in SEM images, copper was accumulated in two layers and lead was accumulated in a single layer on the cuticle crystal layer of the eggshell that was determined by EDS. When comparing the copper-accumulating layers, copper amount was found more on the cuticle crystal layer as a percentage. In addition, it was observed that heavy metals could not penetrate into the eggshells unless there was a hole reaching the palisade layer.

\section{CONCLUSION}

According to ICP-OES results, amount of loaded metal was higher in calcined eggshells. After the eggshells were calcined, the characteristic bands of $\mathrm{CO}_{3}{ }^{2-}$ at 2516 ,
1799 and $713 \mathrm{~cm}^{-1}$ disappeared, while a new band thought to belong to Ca-O appeared at 447 and $455 \mathrm{~cm}^{-}$ 1 for C-CCJ and C-AA respectively. In Cu@CCJ, Cu@AA,Pb@CCJ and Pb@AA, some physical adhesions were observed on the eggshells as a result of FTIR and SEM analysis. In the spectra of Cu@C-CCJ and Cu@C-AA, there were some shifted bands around 400 $\mathrm{cm}^{-1}$. According to the SEM results, 2-layers adhesion was observed on the smooth surface of the Cu@CCJ and Cu@AA. It was seen that both layers formed according to the EDS spots belong to Cu residue. An irregular adhesion was on the holey surface of the Pb@CCJ and Pb@AA.

Lead uptake is higher in both goose and quail eggshells than copper. That is, when these two species are compared, it is seen that lead uptake is higher. 
Regardless of the species, the calcined form facilitates metal uptake. After calcination, the surface of eggshell can mediate to load the metal cations, easily. Calcined form of eggshell may help more porous surface as well as bigger surface area.

When we evaluate the amount of copper and lead over species, the amount of lead uptake shows little difference in almost both species. While copper uptake is less in quail species, it is seen to be higher in goose eggshells. These results reveal two different interpretations. First one, the goose eggshell might be more porous, and second one, the copper atom is smaller in diameter than the lead atom.

In a study, it was concluded that the eggshell pore area decreases with egg size (Chen et al., 2019). If we compare the quail egg size with the goose's one, the inferences are quite meaningful.

\section{REFERENCES}

Alaba, P.A., Oladoja, N.A., Sani, Y.M., Ayodele, O.B., Mohammed, I.Y., Olupinla, S.F., Daud, W.M. (2018). Insight into wastewater decontamination using polymeric adsorbents. Journal of Environmental Chemical Engineering, 6(2): 1651-1672.

Anjaneyulu, U., Sasikumar, S. (2014). Bioactive nanocrystalline wollastonite synthesized by sol-gel combustion method by using eggshell waste as calcium source. Bulletin of Materials Science, 37(2): 207-212.

Awogbemi, O., Inambao, F., Onuh, E.I. (2020). Modification and characterization of chicken eggshell for possible catalytic applications. Heliyon, 6(10), e05283; DOI 10.1016/j.heliyon.2020.e05283

Bae, Y.J., Lee, M., Kim, M.S. (2006). One-Photon MassAnalyzed Threshold Ionization Spectroscopy (MATI) of trans-Dichloroethylene (trans- $\mathrm{C}_{2} \mathrm{H}_{2} \mathrm{Cl}_{2}$ ): Cation Structure Determination via Franck- Condon Fit. The Journal of Physical Chemistry A, 110(27): 8535-8541.

Basaleh, A.A., Al-Malack, M.H., Saleh, T.A. (2019). Metal removal using chemically modified eggshells: preparation, characterization, and statistical analysis. Desalination and Water Treatment, 173: 313-330.

Bhatia, S., George-Taylor, M., Merideth, C., Hall Jr., J.H. (1983). Low-temperature infrared spectrum of chlorine nitrate and evidence for the existence of chlorine nitrate (ClOONO). The Journal of Physical Chemistry, 87(7): 1091-1093.

Chen, X., Li, X., He, Z., Hou, Z., xu, G., Yang, N., Zheng, J. (2019). Comparative study of eggshell antibacterial effectivity in precocial and altricial birds using Escherichia coli. PLoS ONE 14(7): $\quad$ e0220054; DOI /10.1371/journal. pone.0220054

de Luna, M.D., Flores, E.D., Cenia, M.C., Lu, M.C. (2015). Removal of copper ions from aqueous solution by adlai shell (Coix lacryma-jobi L.) adsorbents. Bioresource Technology, 192: 841-844.
Eletta, O., Ajayi, O., Ogunleye, O., Akpan, I. (2016). Adsorption of cyanide from aqueous solution using calcinated eggshells: equilibrium and optimisation studies. Journal of Environmental Chemical Engineering, 4: 1367-1375.

Feng, Y., Ashok, B., Madhukar, K., Zhang, J., Zhang, J., Reddy, K.O., Rajulu, A.V. (2014). Preparation and characterization of polypropylene carbonate bio-filler (eggshell powder) composite films. International Journal of Polymer Analysis and Characterization, 19(7): 637-647.

Gebru, K. A., Das, C. (2017). Removal of Pb (II) and Cu (II) ions from wastewater using composite electrospun cellulose acetate/titanium oxide $\left(\mathrm{TiO}_{2}\right)$ adsorbent. Journal of Water Process Engineering, 16: 1-13; DOI 10.1016/j.jwpe.2016.11.008

Hashmi, M. Z., Malik, R. N., Shahbaz, M. (2013). Heavy metals in eggshells of cattle egret (Bubulcus ibis) and little egret (Egretta garzetta) from the Punjab province, Pakistan. Ecotoxicology and Environmental Safety, 89: 158-165

Hincke, M.T., Chien, Y.-C., Gerstenfeld, L.C., McKee, M.D. (2008). Colloidal-gold Immunocytochemical Localization of Osteopontin in Avian Eggshell Gland and Eggshell. Journal of Histochemistry \& Cytochemistry, 56(5): 467-476.

Kaya Kınaytürk, N., Tunalı, B., Türköz Altuğ, D. (2021). Eggshell as a biomaterial can have a sorption capability on its surface: A spectroscopic research. Royal Society Open Science, 8(6): 1-14; DOI 10.1098/rsos.210100

Kazemi, A., Abdellahi, M., Khajeh-Sharafabadi, A., Khandan, A., Ozada, N. (2017). Study of in vitrobioactivity and mechanical properties of diopsidenano-bioceramic synthesized by a facile method using eggshell as raw material. Materials Science and Engineering: C, 71: 604610.

King'Ori, A.M. (2011). A review of the uses of poultry eggshells and shell membranes. International Journal of Poultry Science, 10(11), 908-912.

Kit, N., Hadibarata, T., Yuniarto, A., Sari, A. (2020). Removal of triphenylmethane dye from aqueous solutions through an adsorption process over waste materials. Biointerface Res. Appl., 10: 5772-5779.

Musonge, P., Harripersadth, C. (2021). The Applicability of Eggshell Waste as a Sustainable Biosorbent Medium in Wastewater Treatment-A Review. Advances in Wastewater Treatment I, 91: 171-192.

Naemchan, K., Meejoo, S., Onreabroy, W., Limsuwan, P. (2008). Temperature Effect on Chicken Egg Shell Investigated by XRD, TGA and FTIR. Advanced Materials Research, 55-57: 333-336.

Pandit, P.R., Fulekar, M. (2017). Egg shell waste as heterogeneous nanocatalyst for biodieselproduction: Optimized by response surface methodology. Journal of Environmental Management, 198: 319-329.

Park, H.J., Jeong, S.W., Yang, J.K., Kim, B.G., Lee, S.M. (2007). Removal of heavy metals using waste eggshell. Journal of Environmental Sciences, 19(12): 1436-1441.

Park, M., Hauge, R.H., Margrave, J.L. (1988). Reactions and photochemistry of atomic and diatomic nickel with water at 15 K. High Temperature Science, 25(1): 1-15.

Pérez-Huerta, A., Dauphin, Y. (2016). Comparison of the structure, crystallography and composition ofeggshells of the guinea fowl and graylag goose. Zoology, 119: 52-63. 
Removal of Heavy Metals (Copper and Lead) Using Waste Eggshell with Two Different Species and Three Different Forms

Podstawczyk, D., Witek-Krowiak, A., Chojnacka, K., Sadowski, Z. (2014). Biosorption of malachite green by eggshells: mechanism identification and process optimization. Bioresource Technology, 160:161-165.

Putra, R.S., Liyanita, A., Arifah, N., Puspitasari, E., Hizam, M.N. (2017). Enhanced electro-catalytic process on the synthesis of FAME using $\mathrm{CaO}$ from eggshell. Energy Procedia, 105: 289-296.

Queiros, M., Bezerra, M., Feitosa, J. (2017). Composite superabsorbent hydrogel of acrylic copolymer and eggshell: effect of biofiller addition. Journal of the Brazilian Chemical Society, 28: 2004-2012.

Reddy, Y., Chary, A., Reddy, S. (2015). DC Ionic Conductivity Study by Two Probe Method on $(1-\mathrm{X}) \mathrm{Pb}\left(\mathrm{NO}_{3}\right)_{2}: \mathrm{XCeO}_{2}$ Composite Solid Electrolyte. Material Science Research India, 12(2): 89-94.

Renu, M.A., Singh, K., Upadhyaya, S., Dohare, R.K. (2017). Removal of heavy metals from wastewater using modified agricultural adsorbents. Materials Today: Proceedings, 4(9): 10534-10538.

Tangboriboon, N., Suttiprapar, J., Changkhamchom, S., Sirivat, A. (2019). Alternative green preparation of mesoporous calcium hydroxyapatite by chemical reaction of eggshell and phosphoric acid. International Journal of Applied Ceramic Technology, 16(5): 1989-1997.

Tatzber, M., Stemmer, M., Spiegel, H., Katzlberger, C., Haberhauer, G., Gerzabek, M. (2007). An alternative method to measure carbonate in soils by FT-IR spectroscopy. Environmental Chemistry Letters, 5: 9-12.

Tizo, M.S., Blanco, L.A., Cagas, A.C., Cruz, B.R., Encoy, J.C., Gunting, J.V., Arazo, R.O., Mabayo, V.I. (2018). Efficiency of calcium carbonate from eggshells as an adsorbent for cadmium removal in aqueous solution. Sustainable Environment Research, 28(6): 326-332.

Tsai, W., Yang, J., Lai, C., Cheng, Y., Lin, C., Yeh, C. (2006). Characterization and adsorption properties of eggshells and eggshell memrane. Bioresource Technology, 97: 488493.
Veli, S., Alyuz, B. (2007). Adsorption of copper and zinc from aqueous. Journal of Hazardous Materials, 149: 226-233.

Waheed, M., Butt, M.S., Shehzad, A., Adzahan, N.M., Shabbir, M.A., Suleria, H.A., Aadil, R.M. (2019). Eggshell calcium: A cheap alternative to expensive supplements. Trends in Food Science \& Technology, 91: 219-230.

Wallington, T.J., Barnes, I., Becker, K.H., Sehested, J., Nielsen, O.J. (2000). Stability and infrared spectra of mono-, di-, and trichloromethanol. Chemical Physics Letters, 322(1-2): 97-102.

Wang, B., Xia, J., Mei, L., Wang, L., Zhang, Q. (2018). Highly efficient and rapid lead (II) scavenging by the natural artemia cyst shell with unique three-dimensional porous structure and strong sorption affinity. ACS Sustainable Chemistry \& Engineering, 6(1): 1343-1351.

Yang, S.C., Liao, Y., Karthikeyan, K.G., Pan, X.J. (2021). Mesoporous cellulose-chitosan composite hydrogel fabricated via the co-dissolution-regeneration process as biosorbent of heavy metals. Environmental Pollution, 286(117324); DOI 10.1016/j.envpol.2021.117324

Yu, W., Hu, J., Yu, Y., Ma, D., Gong, W., Quu, H., Hu, Z., Gao, H.W. (2021). Facile preparation of sulfonated biochar for highly efficient removal of toxic $\mathrm{Pb}$ (II) and $\mathrm{Cd}$ (II) from wastewater. Science of The Total Environment, 750(141545); DOI 10.1016/j.scitotenv.2020.141545

Yusuff, A. S. (2017). Preparation and characterization of composite anthill-chicken eggshell adsorbent: optimization study on heavy metals adsorption using response surface methodology. Journal of Environmental Science and Technology, 10: 120-130.

Zhang, S., Huang, Z., Wang, H., Liu, R., Cheng, C., Guo, Z., Yu, X., He, G., Fud, W. (2021). Separation of wolframite ore by froth flotation using a novel "crab" structure sebacoyl hydroxamic acid collector without $\mathrm{Pb}\left(\mathrm{NO}_{3}\right)_{2}$ activation, 389: 96-103. 